\title{
The Role of Decision-making by the Head Room against the Compliance of Nurses in the Implementation of Hand Hygiene
}

\author{
Indah Dwi Rahayu'*, Tri Kurniati ${ }^{2}$, AbdulAziz Alimul Hidayat ${ }^{3}$ \\ ${ }^{12}$ Faculty of Nursing, University of Muhammadiyah Jakarta, Indonesia \\ Jalan. Cempaka Putih Tengah I/1 Jakarta Pusat 10510 \\ ${ }^{3}$ Faculty of Nursing, University of Muhammadiyah Surabaya, Indonesia \\ Jalan Raya Sutorejo No. 59, Mulyorejo, Surabaya, 60113 \\ *Corresponding author: indadwihrahayu@yahoo.co.id
}

\begin{abstract}
Background: The facts there are still have nurses who are not obedient in the performance of hand hygiene. The role performed by the head room is expected to motivate and improve compliance hand hygiene in the implementing by the nurse so the quality and the indicators of the quality of the hospital can be increased. Objective: explain the influence of the Role of decision-making the head room against the Compliance of nurses in the performance Hand Hygiene. Research used descriptive analytic with Cross Sectional. Method: The data analysis used chi-square. Results: The results showed that there was a meaningful relationship between the role of the decision-making of the head room against the compliance of nurses in the implementation hand hygiene, negotiators roles 0,001 $(P<0.05)$, resource allocator roles $0.009(P<0.05)$, and disturbance handler roles is 0.001 $(P<0.05)$. Conclusion: the role of decision-making of the head room is one of the factors that influence compliance hand hygiene in the nurses' implementation, with the role of head room made nurses increase the compliance. Thus the indicator to the quality of patient safety in the hospital can be achieved.
\end{abstract}

Keywords: Hand hygiene, Nurses Compliance, The Role of decision-making.

\section{INTRODUCTION}

One of the goals of patient safety is to low the risk of infection with hand hygiene. Appropriate hand washing procedure is desirable to prevent the occurrence of Health-care Associated Infections (HAIs). The application of the appropriate hand hygiene procedure by health workers is currently still low. In General, the level of fulfillment of hand hygiene in accordance the procedure by health workers is under 50\% (Septiani, 2016). The head room as the Manager must be able to carry out its role in the management of nursing. The role and functions of the head of the room is very important in performing the organizational setting in a ward of a hospital. The role and function of head room, such as; identify problems, plan work function, planning, organizing and controlling the overall conduct of the organization. While own manager which means someone whose primary responsibility is to conduct the management process in an organization has the role of interpersonal roles, the roles of giver, role information and decision making.

Compliance, as the end of the destination itself, on a health program (Patient Safety) is a behavior that can be observed and thus can be directly measured which is expected to be 
owned by all the implementing authority nurse in running the job who commissioned to provide nursing services directly to clients (Niven, 2012). The implementation of a good role by a Manager is known as one of the factors that affect to increase in compliance of nurses. This research aims to study the influence of the decision-making role of the head room against the compliance of nurses implementing of the provision of hand hygiene in the hospitalization room.

\section{METHOD}

This research used descriptive analytic design research with cross sectional approach. This research population is the managing nurses who were on inpatient room, diploma nursing and ners about 229 with sample amount 146 in accordance with criteria of inclusion that is at least 1 year working period. Sampling used technique of Purposive Sample. Independent variable is the decision-making role of head room and the dependent variable is the compliance of nurses implementing the provision of hand hygiene.

The data is drawn from this research used questionnaire instruments took during two weeks in five working days. The process of research is since the preparation until the end lasted 4 months (April-July 2017). Research instrument was a questionnaire which consists of three parts, namely, the role of nurses data for decision making head room 16 questions (Likert scale), and10 questions nursing knowledge (scale Guttman). The instruments developed by the researcher based on the associated theory.

Instrument test conducted on nurses in the room of inpatient another hospital not be research respondents $(n=30)$. The hospital chosen is expected to have the same characteristics of the respondents of the study. Processing and analysis of data used for univariate frequency distributions, while analysis bivariate used statistical test of chi square.

\section{RESULTS AND DISCUSSION}

Characteristics of respondents can be shown in table 1 shows that 146 respondent's diploma nursing about 126 respondents (86.3\%), female $78.1 \%$ and $21.9 \%$ male. The mean age average of the respondents is about 33.66 -with an average year long work about 9.05 years.

Table 1 Characteristic distribution respondents in Dr. Soedarso hospital at 2017 n=146

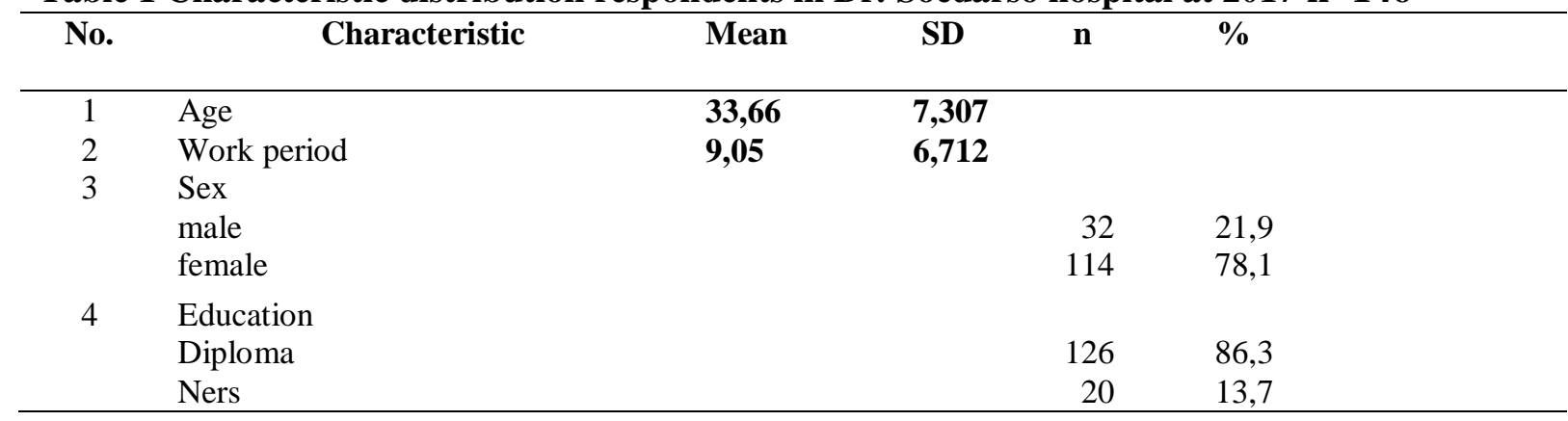

Table 2 shown the proportion of the distribution respondents associated the decisionmaking role of the head room against the compliance of implementing nurse. The proportion of respondents associated the decision-making role of the head room that suits the role about 
114 respondents $(78.1 \%)$, while the proportion of nurses who dutifully toward the implementation of hand hygiene about 68 respondents (46.6\%). On the decision-making role of variable sub head room related entrepreneur implemented in accordance with the role as much as $74.7 \%$, Negotiator of the head room that matches with the role as much as $56.2 \%$, while for the resource allocator head room in accordance with the role as much as $47.3 \%$ and associated disturbance handler of the head room that fits to the role as much as $64.4 \%$. The results of the analysis of the dependent variables (compliance with hand hygiene in implementing nurse there are 4 sub related compliance, variable stage availability while the nurse dutifully as much as $50 \%$, at this stage of the process of identifying the way ward nurses as much as $50 \%$, and at this stage of the wayward nurses of internalization as much as $54.8 \%$. While for a good knowledge nurses who dutifully about $98.6 \%$.

Table 2 Distribution variable the role of decision-making head of the room and variable compliance nurse implementing in handle of hand hygiene at Dr. Soedarso hospital Pontianak 2017, $n=146$

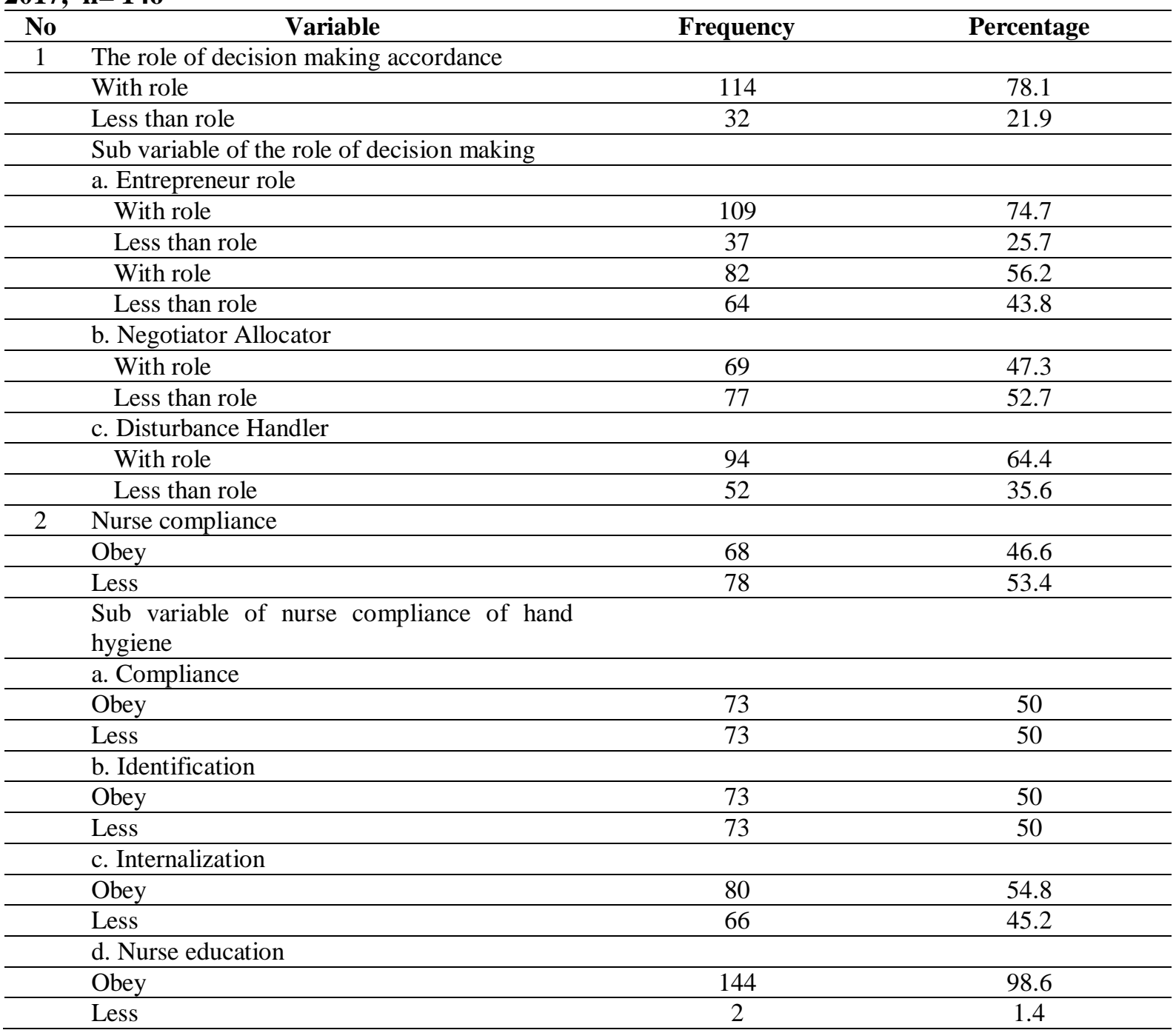


Table 3 shows the analysis of the influence of the decision-making role of head nurse in compliance with implementation of hand hygiene in the inpatient hospital Pontianak in 2017. The proportion of the decision-making role of the head room that less accordance about $90.6 \%, 29$ nurses less obediently in the performance of hand hygiene. While $57 \%$ of the 65 respondents felt the decision-making role of the head room fit in improving compliance in the implementation of hand hygiene in the room. The analysis further concluded that there was a meaningful relationship between the decision-making role of head nurse's compliance with implementing the provision of hand hygiene $(\mathrm{p}=0.000<0.05)$. Based on the results of the analysis obtained values $\mathrm{OR}=12.823$, which emphasizes the role of the head decisionmaking appropriate chance to 12.8 times more wayward nurses make in the performance of hand hygiene compared the role of decision making the head of a less appropriate rooms (95\% CI: 3,692-44,541).

Table 3 Analyze the role influence of decision making the head room to compliance of the nurse in handle of hand hygiene at Dr. Soedarso hospital Pontianak 2017, n= 146

\begin{tabular}{|c|c|c|c|c|c|c|c|}
\hline \multirow[t]{3}{*}{ Variable } & \multirow{2}{*}{\multicolumn{4}{|c|}{ Nurse compliance }} & \multirow{3}{*}{$\begin{array}{l}\mathrm{f} \\
\mathrm{n}\end{array}$} & \multirow{3}{*}{$\begin{array}{c}\text { OR } \\
(95 \% \mathrm{CI})\end{array}$} & \multirow{3}{*}{$\begin{array}{l}\text { P value } \\
\%\end{array}$} \\
\hline & & & & & & & \\
\hline & $\mathrm{n}$ & $\%$ & $\mathrm{n}$ & $\%$ & & & \\
\hline \multicolumn{8}{|c|}{ Independent variable } \\
\hline \multicolumn{8}{|c|}{ The of decision making } \\
\hline Less & 65 & 57 & 49 & 43 & 114 & 12,823 & 0,001 \\
\hline Appropriate & 3 & 9.4 & 29 & 90.6 & 32 & $(3,692-44,541)$ & \\
\hline \multicolumn{8}{|l|}{ a. Entrepreneur } \\
\hline Appropriate & 63 & 43.2 & 46 & 31.5 & 109 & 8,765 & 0,001 \\
\hline Less & 5 & 3.42 & 32 & 21.9 & 37 & $(3,172-24,217)$ & \\
\hline \multicolumn{8}{|l|}{ b. Negotiator } \\
\hline Appropriate & 54 & 37 & 28 & 19.2 & 82 & 6,888 & 0,001 \\
\hline Less & 14 & 9.6 & 50 & 34.2 & 64 & $(3,260-14,553)$ & \\
\hline \multicolumn{8}{|c|}{ c. Resource Allocator } \\
\hline Appropriate & 40 & 27.4 & 29 & 19.8 & 69 & 2,414 & 0,009 \\
\hline Less & 28 & 19.2 & 49 & 33.6 & 77 & $(1,240-4,700)$ & \\
\hline \multicolumn{8}{|c|}{ d. Disturbance Handler } \\
\hline Appropriate & 55 & 37.7 & 39 & 26.7 & 94 & 4,231 & 0,001 \\
\hline Less & 13 & 8.9 & 39 & 26.7 & 52 & $(1,999-8,956)$ & \\
\hline
\end{tabular}

The role and functions of the head room determines the standard of success that poured in the form of targets, work procedures and the appearance of the staff that will be compared with results that have been achieved or able of being worked by staff (Marquis \& Huston, 2010). The results of the research on knowledge obtained of the nurses in inpatient Hospital Dr. Soedarso Pontianak just 2 people nurses who have low knowledge; this indicates that most nurses know the correct implementation of the hand an appropriate standard of hygiene.

Parhinahingsih research results (2008) in Septiani, DA. (2016) also suggests that there are other factors that can affect the behavior of the application of hand hygiene, among others, education, interests, jobs, information, culture, age and experience. In theory it is said 
that the higher the level of knowledge of nurses about hand hygiene is expected to have the appropriate behavior when applying the principle of hand hygiene. This indicates that respondents only knew but could not be applied (Septiani, 2016). According Bloom's theory in Notoatmodjo (2010) States that the domain of knowledge starting from the idea to the domain of the application. Domain know just know about the principle - the principle of hand hygiene but not yet stemmed the behavior when in the field. Bloom also explained that the behavior is not only influenced by knowledge alone, but can be influenced by the supporting factors (availability of facilities of hand hygiene) and the driving factor (fixed hand hygiene procedures) (Notoatmojo, 2010)

It is concerned the decision-making role of the head room, as well as the Role of the head room in order to improve compliance with hand hygiene in the implementation of nurse is very necessary, as for how that can be done to a head room role oversight and decisionmaking as well as the routine construction, consistently and continuously so that compliance with the nurses in the implementation of hand hygiene can continue to increase the quality of service and the quality would be good. The head room is a great role model for his subordinates, then it should also commence compliance from head room that can always be an example to all the nurses there were coated in order to improve the quality of service. For example in innovation head room can perform the role of negotiator in increased compliance of nurses in the provision of infrastructure so that compliance of nurses is increasing.

\section{CONCLUSION}

The results of statistical tests in this study prove that there is influence the decisionmaking role of the head room against the compliance of nurses in the performance of hand hygiene. From these results the management hospitals can perform evaluation related roles that have been run to enhance compliance of nurses who are currently still less considered, such as enacting reward and punishment, motivation, conduct in-house training and implement climate work culture which can improve compliance with nurses.

\section{ACKNOWLEDGMENT}

Researchers say thanks to Director RSUD Dr. Soedarso Pontianak, Director Dr. Abdul Aziz Singkawang, My beloved parents, husband and my lovely girls, my brother and Mr. Cau Kim Jiu that have helped the process of collecting the data used in this study.

\section{REFERENCES}

Marquis and Huston. (2010). Kepemimpinan dan manajemen keperawatan. Teori dan Aplikasi. Alih bahasa: Widyawati dan Handayani. Jakarta. Edisi 4. EGC, pp: 2-23.

Marquis, B.L dan Huston, C.J. (2000). Ledership Roles and Menegemen Function in Nursing. Philadelphia: Lippincott Company

Niven, N. (2012). Health Psychology An Introduction for Nurses and Other Health Care Profesionals. Jakarta: EGC, pp: 192-198.

Notoatmojo, S. (2010). Ilmu Perilaku Kesehatan. Jakarta: Rineka Cipta Purwidiana., pp: 2629 
Septiani, DA. (2016). Overview Of Factors That Affecting Nurse Hand Hygiene in Ar Royan's Ward at PKU Muhammadiyah Hospital Gamping Sleman. 